\title{
How to Enfranchise Second Country Nationals? Test the Options for Best Fit, Easiest Adoption and Lowest Costs
}

\author{
David Owen
}

The proposal of this ECI by Philippe Cayla and Catriona Seth is a welcome initiative addressing a problem that has already been highlighted by the European Commission', namely, that some 'second country nationals' (SCNs) lose their entitlement to vote in the national elections of their state of nationality without having acquired the right to vote at this level in their state of residence. This is a democratic wrong since it is not democratically legitimate that a person lawfully exercising a civil right shall in virtue of such exercise be deprived of a political right. The democratic harm that results is, given the political constitution of the EU, not simply that the disenfranchised individual has no say in who represents them in the national legislature or executive but also, consequently, that they have no say in relation to who represents them at the Council of Ministers. While I share Andrew Duff's view that 'the rights prescribed in Articles 39 and 40 of the EU Charter of Fundamental Rights concerning voting and standing in local and European elections' are not 'as comprehensive as the citizen rightly demands', I see little reason to think that this situation will change with the EU's signing up to the ECHR, not least since 'the people' is one of the more complex and contested terms in the legal and political lexicon.

How, then, is this demos problem best addressed? Four simple general rules are available as options for resolving the legitimacy deficit that characterises the status quo:

1. All SCNs have national voting rights in the state of residence.

2. All SCNs have national voting rights in the state of nationality.

3. All SCNs have the choice between (1) and (2).

4. All SCNs have a time-differentiated combination of (1) and (2) which starts with (2) and, after a period of residence, switches to (1).

It is notable that (2)-(4) can be, more or less, combined in a more complex rule:

European Commission (2010), EU Citizenship Report 2010: Dismantling the obstacles to EU citizen's rights, $\operatorname{COM}(2010) 603$ final. 
5. All SCNs shall have a fair opportunity of acquiring nationality in the member state of residence and all SCNs who do not have nationality in their member state of residence shall be eligible to vote in national elections of their member state of nationality.

Any of these five general rules would suffice to address the democratic wrong but which is the best choice? Or, to tie our discussion back to the proposed ECI, why ought we privilege (1)? There are three dimensions to the issue of which is the best choice. First, which rule offers the best fit with the institutional structure of the EU? Second, which rule is easiest to adopt and implement? Third, what are the likely costs and side-effects of the different rules?

On the first score, the ECI proposal does not do well because it misconstrues the current composition of the EU as a polity. This claim can be elucidated by contrasting the EU with purely intergovernmental and fully federalised systems that are also committed to free movement within the territorial area that they cover. In the case of a purely intergovernmental structure, the norm of free movement is grounded on a joint commitment to a shared aim or purpose such as, for example, a European market. In terms of the national citizenship of the states involved in this intergovernmental project, the context remains largely equivalent to that of independent states who are not engaged in such a project, but not wholly since the shared purpose brings into play the principle that the partners to this project should not act to frustrate this joint enterprise and should, where compatible with their distinct national contexts and projects, aim to facilitate it. Such a principle could be expressed by, for example, offering preferential treatment to the citizens of partner states for access to membership rights and for dual citizenship.

In the contrasting case of a fully federalised system, free movement may serve instrumental purposes but fundamentally expresses a basic liberty of citizens as federal citizens which requires that anyone exercising their right to cross state borders must not be disadvantaged at any level of the franchise within the federal structure. An obvious way to respect this democratic commitment is to adopt a residence-based rule for voting rights in the states that comprise the federal union. But the EU is neither a purely intergovernmental nor a fully federalised body. Because it isn't simply intergovernmental it is a democratic wrong for EU citizens who move across state borders to lose national voting rights; because it isn't simply federal the ECI proposal of a residence-based voting rule isn't an ideal fit as a way of ensuring political equality for EU citizens. Option (5), rather than option (1), looks like the 
best rule here because it aligns responsibility for political rights of nationals in the right way, that is, to the member states through which EU citizenship is acquired.

Option (5) does less well though on the second dimension. As Alain Brun rightly observes, it is likely to be 'tricky' and 'difficult' to get all member states of the EU to coordinate their national legislation in this way (particularly if they have constitutional provisions against expatriate voting). Here Brun's suggestion of adopting option (3) and the ECI proposal of option (1) both look more straightforward and exhibit greater continuity with existing EU practices. This matters because it is relevant to ask not just what fits best but how long it will take to remove the democratic wrong and harms at stake here.

On the third dimension, option (1) has both strong positives and negatives. On the positive side, it provides political representation in an SCN's immediate context of governance and it would also resolve the quite radical disparities between the implementation of the EU rule on local voting rights (consider the comparison of France and the UK, for example, where in France local voting rights are restricted to the level of the commune, while it the UK they include not only local and county council elections but also extend to voting in devolved assembly elections in Scotland, Wales and Northern Ireland) since it would remove any constraints that pertain to the linkage of local and national representation (as occur, for example, in France where members of the Senate are chosen through an electoral college comprised on locally-elected officials). On the negative side, option (1) completely severs the political relationship between citizen and their state of nationality and also breaks the widely held link between citizenship of the state and voting rights (although this link does not hold universally even between EU member states, as the mutual granting of voting rights between the Republic of Ireland and the UK illustrates). Option (3) is, arguably, worst here since it provides the choice of either political representation in the immediate context of national rule or maintaining a political link with one's state of nationality without resolving disparities in relation to local voting and while breaking the citizenship-franchise link at national level. Option (5) delivers neither the strong positives nor the negatives of option (1). It maintains the linkage between national citizenship and suffrage at national level, and is likely to support a general easing of access to nationality of the state of residence for third country nationals in the same way that EU rules on local voting have supported their extension to third country nationals in a number of states. 
So which option is best? Although I share Rainer Bauböck's preference for option (5), I think that there is still a strong case for option (1) - and for this reason I would sign the ECI.

Open Access This chapter is licensed under the terms of the Creative Commons Attribution 4.0 International License (http://creativecommons.org/licenses/by/4.0/), which permits use, sharing, adaptation, distribution and reproduction in any medium or format, as long as you give appropriate credit to the original author(s) and the source, provide a link to the Creative Commons license and indicate if changes were made.

The images or other third party material in this chapter are included in the chapter's Creative Commons license, unless indicated otherwise in a credit line to the material. If material is not included in the chapter's Creative Commons license and your intended use is not permitted by statutory regulation or exceeds the permitted use, you will need to obtain permission directly from the copyright holder. 